\title{
Sustainable Reporting and Profitability of Quoted Firms in Nigeria: A Multi-Dimensional Panel Data Study
}

\author{
Ngozi G. Iheduru \\ Associate Professor \\ Department of Accountancy \\ Faculty of Business Administration \\ Imo State University \\ Owerri, Nigeria \\ Charles U. Okoro \\ M. Sc Student \\ Department of Accountancy \\ School of Management Sciences \\ Ken Saro Wiwa Polytechnic \\ Bori, Rivers State, Nigeria
}

\begin{abstract}
This paper used cross sectional data to examine the effect of sustainable reporting on the profitability indicators of Nigeria quoted firms between 2008-2017. Data was sourced from financial statement of the firms. Twenty firms were selected from the population of quoted firms in Nigeria. Return on equity, earnings per share and return on investment were proxy for profitability while sustainable reporting was proxied by economic, social, environmental and corporate governance disclosure. The panel data model was tested using the Hausman test. Model one and two validated the fixed effect while model three validated the random effect. The results found that economic disclosure and social disclosure have positive but insignificant effect on return on equity of the selected firms while environmental and corporate governance disclosure have negative and insignificant effect on return on equity, all the predictor variables have positive and insignificant effect on earnings per share of the firms and that economic, social and environmental disclosure have positive effect on return on investment while corporate governance disclosure have negative effect on return on investment of the selected firms in Nigeria. We recommend that operating environment of the firms should be well examined and policies should be advanced to manage factors such as economic, social, environmental and corporate governance disclosures to leverage the environmental challenges and enhance profitability, companies should ensure strict compliance to all forms

of sustainability reporting.
\end{abstract}

Keywords: Sustainable Reporting, Profitability, Quoted Firms, Panel Data Study

\section{Introduction}

The objective of shareholders wealth maximization is an appropriate and operationally feasible criterion to choose among the alternative financial actions. Organizations are generally established with an objective to maximize shareholders welfare while remaining profitable (Aggarwal, 2013). More often than not, activities carried on by these organizations tell on their immediate environment as well as the environment at large. It provides an unambiguous measure of what financial management should seek to maximize in making decisions such as investment, dividend policy and financing decisions on behalf of shareholders (Burhan and Rahmanti, 2012). Financial goals are quantitative expression of corporate missions and strategies and are set by its long-term planning system as a tradeoff among conflicting and competing interest (Duke II, \& Kankpang, 2013). These financial goals guides the maximization of book value of net worth, market value per share, cash flow, operating profit before interest and tax, maximizing the ratio of price earning, market rate of return, return on investment, net profit to net worth, net profit margin, market share and maximization of the growth in earnings per share, total assets, sales and ensuring availability of funds(Pandey, 2015).

Every corporate organization operate in an environment where it takes input from processed to finished or semifinish product to the environment (Akani and Briggs, 2018). This process results in externalities which is the cost and benefit of the corporate organization to the environment. Environmental accounting involves the identification, measurement and allocation of environmental costs and the integration of these costs into the business and 
encompasses the way of communicating such information to the stakeholders (Horvathora, 2010). The concept of sustainability reporting maintains that while a firm strives to achieve its traditional objectives of profit maximization, it is important that this profit is maximized through activities that seek to integrate social and environmental considerations into the decision-making process. Historically advocacy for corporate sustainability reporting by leading governments has been on the increase with the coming together of Brazil, Denmark, France and South Africa, in support of the United Nations Conference on Sustainable Development (Rio+20). The aforementioned countries attracted the support of the Global Reporting Initiative and United Nations Environment Programme (UNEP).

Organizations engage in sustainability reporting to enhance their competitiveness, in comparison with other companies producing similar product (Jones, 2010). Competitiveness or standing out among other organizations can be traced to the goodwill or intangible asset value of the firm because it cannot be physically measured in monetary terms. A company's social and environmental issues can materially affect its overall performance in terms of corporate image and reputation (Makori and Jagongo, 2013: Aondoakaa, 2015; Babalola and Abiodun, 2012; Munasinghe and Kumara, 2013; Khaveh, Nikhashemi, Yousefi and Haque, 2012). The reporting of these issues among other corporate sustainability indicators can be traced to demands from various stakeholder groups such as investors, customers, employees, Non-Governmental Organizations, media and community, for increased levels of transparency and disclosure, ethical reasons and community concerns. While there are many studies on financial disclosure and corporate profitability, there is limited study citabledealing with the problem of sustainable reporting and profitability of quoted firms in Nigeria, therefore this study examined the effect of sustainable reporting on profitability indicators of Nigeria quoted firms.

\section{Literature Review}

\section{Concept of Sustainable Reporting}

Sustainability Reporting is a subset of accounting and reporting that deals with activities, methods and systems to record, analyze and report, firstly, environmentally and socially induced financial impacts and secondly, ecological and social impacts of a defined economic system (Jasch and Stasiskiene, 2005). Sustainability Reporting deals with the measurement, analysis and communication of interactions and links between social, environmental and economic issues constituting the three dimensions of sustainability. Sustainability Reporting is becoming more prevalent, driven by a growing recognition that sustainability related issues can materially affect a company's performance, demands from various stakeholder groups for increased levels of transparency and disclosure and the need for companies (and the business community more generally) to appropriately respond to issues of sustainable development (Ivan, 2009). It is the practice of measuring, disclosing and being accountable to internal and external stakeholders for organizational performance towards the goals of sustainable development.

\section{Theoretical Framework}

\section{Stakeholder theory}

The traditional definition of a stakeholder is any group or individual who can affect or is affected by the achievement of the organization's objectives (Fontaine, Harman and Schmid, 2006). The general idea of the stakeholder concept is a redefinition of the organization. In general, the concept is about what the organization should be and how it should be conceptualized. Popa, Blidisel and Bogdan (2009) maintains that stakeholder theory is based on the premise that the stronger the companies relationships are with other interest parties, the easier it will be to meet its business objectives. Stakeholder theory contributes to the corporate sustainability concept by bringing supplementary business arguments as to why companies should work toward sustainable development. Perrini and Tencati (2006) stated that the sustainability of a firm depends on the sustainability of its stakeholder relationships; a company must consider and engage not only shareholders, employees and clients, but also suppliers, public authorities, local community and civil society in general, financial partners.

\section{Legitimacy Theory}

Legitimacy theory is derived from political economy theory and relies on the idea that the legitimacy of a company to operate in society depends on an implicit social contract between the company and society. As described by Deegan (2000) legitimacy theory asserts that organizations continually seek to ensure that they operate within the bounds and norms of their respective societies, that is, they attempt to ensure that their activities are perceived by outside parties as being legitimate. Managers continually attempt to ensure that their company complies with its social contract by operating within society's expectations. This suggests that managers have incentives to disclose information that indicates that the company is not in breach of the norms and expectations of society, therefore, the company attempts to maintain its survival and continuity by voluntarily disclosing detailed information to society to prove it is a good citizen.

\section{Political Economy Theory}


The political economy has been defined by Gray et al. (1996) in Deegan (2007)as the social, political and economic framework within which human life takes place. Political economy theory explicitly recognizes the power conflict that exist within society and the various struggles that occur between various groups within the society.

The perspective embraced in political economy theory is that society, politics and economics are inseparable and economic issues cannot meaningfully be investigated in the absence of considerations about the political, social and institutional framework in which the economic activity takes place. It is argued that by considering the political economy a researcher is better able to consider broader (society) issues which impact on how an organization operates, and what information it elects to disclose.

Following from the above point, Guthrie and Parker (1990) in Deegan (2007:130) explain the relevance of accounting within a political economy perspective. They state that the political economy perspective perceives accounting report as social, political and economic documents. They serve as a tool for constructing, sustaining, and legitimizing economic and political arrangements, institutions and ideological themes which contribute to the corporation's private interests. Political economy theory relies on the concept that society, politics and economics are indivisible and economic events cannot be studied in comprehensive manner without reference to political, social and institutional framework in which the event occurs. A study of political economy allows researchers to contemplate broader issues about the information companies elect to disclose in their annual reports (Guthrie and Parker, 1990 in Kenth and Stewart, 2008).

\section{Accountability Theory}

Accountability theory is concerned with the relationship between groups, individuals, organizations and the rights to information that such relationships bring about. Accountability is an act of being responsible or answerable for one's own decisions or actions with the expectation of explaining and justifying them when asked to do so. Simply stated, accountability is the duty to provide an account of the actions for which one is held responsible (Gray et al., 1991). The natures of the relationships and the attendant rights to information are contextually determined by the society in which the relationship occurs. It is absolutely true that some sort of relationship will exist between an organization and each of its stakeholders. Part of this relationship may be economic in nature and the terms determined by the parties as reflecting their relative powers in the relationship. The information flowing through the relationship will be determined by the power of the parties to demand it and the willingness of the organization to provide it (Gray et al., 1997).

\section{Empirical Review}

Asuquo, Dada and Onyeogaziri (2018)examined the effect of sustainability reporting on corporate performance of selected quoted brewery firms in Nigeria. To determine the association between sustainability reporting and corporate performance, data was obtained from the audited financial statements of the three brewery firms under study for a period of five years (2012-2016). The result of the study shows that Economic Performance disclosure (ECN), Environmental Performance disclosure (ENV) and Social Performance disclosure (SOC) have no significant effect on return on asset (ROA) of selected quoted firms in Nigeria.

Olayinka and Temitope (2011) empirically examined the relationship between corporate social responsibility and financial performance in Nigeria and found out that corporate social responsibility has a positive and significant relationship with the financial performance measures, Yahya and Ghodratollah (2014) employed multiple-linear regression analysis to investigate the impact of corporate social responsibility disclosure (CSRD) on the financial performance of companies listed on the Tehran stock exchange. The independent variable (CSRD) was measured by economic, social and environmental indices while Return on Assets, Return on Equity and Price Earnings Ratio were used in measuring financial performance. The analysis produced inconsistent results.

Onyekwelu and Ekwe (2014) Used ordinary least square regression to examine whether corporate social responsibility predicates good financial performance using the banking sector in Nigeria. The findings of their study show that the amount committed to social responsibility vary from one bank to the other. It further revealed that the sample banks invested less than ten percent of their annual profit to social responsibility. Onyekwelu and Ugwuanyi (2014) carried out a research on Corporate Social Accounting and Enhancement of Information Disclosure among Firms in Nigeria and found out that the inclusion and separate presentation of social costs incurred by organizations in the financial statements will enhance information disclosure in the statement.

Nze, Okoh and Ojeogwu (2016) examined using the ordinary regression analysis the effect of corporate social responsibility on earnings of quoted firms in Nigeria in the oil and gas sector over a ten-year period and found out that corporate social responsibility has a positive and significant effect on earnings of firms studied.

Babalola and Abiodun (2012) concluded that variations in selected firms performance were caused by changes in CSR reporting after analyzing ten firms in Nigeria for over 1999-2008. Aupperle, Carroll and Hatfield (1985) analyzed the relationship between corporate social responsibility and profitability of the companies listed in Forbes 1981 Annual Directory and concluded that there was no relationship between social responsibility and profitability. 
Murray, Sinclair, Power and Gray (2006) studied the relationship between social and environmental performance disclosure and financial market performance of companies in UK and found no significant relationship between environmental reporting and market performance.

Aggarwal (2013) ascertained whether sustainable companies are more profitable. Using regression analysis, he established that sustainability has significant but varying impact on financial performance. Munasinghe and Kumara (2013) ascertained the relationship between Corporate Social Responsibility (CSR) and financial performance to see what motivates firms to voluntary initiate CSR activities. Using Spearman's rank-order correlation they found out that Return on Equity and Return on Assets were positively correlated and significant.

Makori and Jagongo (2013) investigated into whether there is any significant relationship between environmental accounting and profitability of selected firms listed in India. Using multiple regression analysis, they found that there is significant negative relationship between Environmental Accounting and Return on Capital Employed (ROCE) and Earnings per Share (EPS) and a significant positive relationship between Environmental Accounting and Net Profit Margin and Dividend per Share.

Robbins (2011) found that most executives believe that corporate social responsibility reporting can improve profits. They understand that corporate social responsibility can promote respect for their company in the market place which can result in higher sales, enhance employee loyalty and attract better personnel to the firm. Also, corporate social responsibility reporting activities focusing on sustainability issues may lower costs and improve efficiencies as well. Robbins (2011) observed that reviewing individual empirical studies can be confusing. But by using the technique of Meta-analysis many studies can be statistically analyzed to determine collective results. Duke and Kankpang (2013) ascertained the effect of corporate social responsibility activities on the financial performance of firms operating in some of the industries that have the greatest impact on the environment in Nigeria. Using multiple regression analysis they revealed that waste management, pollution abatement are both significantly and positively associated with firm performance. Makori and Jagongo (2013) investigated into whether there is any significant relationship between environmental accounting and profitability of selected firms listed in India. Using multiple regression analysis they found that there is significant negative relationship between Environmental Accounting and Return on Capital Employed (ROCE) and Earnings per Share (EPS) and a significant positive relationship between Environmental Accounting and Net Profit Margin and Dividend per Share. Researching on the impact of sustainability performance of company on it financial performance, a study of Indian companies Aggarwal (2013) ascertained whether sustainable companies are more profitable. Using regression analysis he established that sustainability have significant but varying impact on financial performance. Munasinghe and Kumara (2013) ascertained the relationship between Corporate Social Responsibility (CSR) and financial performance to see what motivates firms to voluntary initiate CSR activities. Using Spearman's rank-order correlation they found out that Return on Equity and Return on Assets were positively correlated and significant. The empirical studies examined above are mainly foreign studies with few studies of citable significant on the Nigeria business environment.

\section{Methodology}

This study used quasi experimental research design.. This approach combines theoretical consideration (a prior criterion) with the empirical observation and extract maximum information from the available data. It enables us therefore to observe the effects of explanatory variables on the dependent variables.

Firms that were studied are those that are quoted on the floor of Nigerian Stock Exchange (NSE). The target size of 20 quoted firms was drawn from various sub-sections/industries, based on the NSE classification. The Annual Financial Statements of the respective firms for ten years running were our major focus. The necessary data for our analysis were obtained from various years of NSE Fact-book. The study adopted the longitudinal time dimension, specifically the panel study type. The panel regression equation is different from a regular time-series or cross section regression by the double subscript attached to each variable. The general form of the panel data model is specified as:

$$
y_{i}, \alpha+\beta X_{i, t}+\varepsilon_{i, t} 1
$$

The subscript $i$ denotes the cross-sectional dimension and $t$ represents the time-series dimension. The left-hand variable $y$ represents the dependent variable in the model which represents the value relevance of firms listed on the Nigeria Stock Exchange, $\beta x$ contains the set of explanatory variables in the estimation model, $\alpha$ and is taken to be constant overtime $t$ and specific to the individual cross-sectional unit

\section{Model Specification}


The objective of this section is to develop models to employ to find the validity of the hypothesis: that sustainability reporting enhances profitability of quoted firms.. Multiple Linear Regression Technique (applying time series), and Analysis of Variance Technique was used to generate the models in this study. The study used positive quantitative research paradigm which is appropriate because it enables the capturing of knowledge through measurements of phenomena in which mathematical and statistical procedures are used to describe, predict and explain behavioral phenomena (Krasuses, 2005). The study is basically a quantitative research that aimed at examining the effect of sustainable reporting on profitability indicators of Nigeria quoted firms.

$$
\begin{aligned}
& R O E=f(E C D, S O D, E N V D, C G D) \\
& E P S=f(E C D, S O D, E N V D, C G D)_{3} \\
& R O 1=f(E C D, S O D, E N V D, C G D)
\end{aligned}
$$

The regression models are thus formulated as

$$
\begin{aligned}
& R O E=\beta_{0}+\beta_{1} E C D_{i}+\beta_{2} S O D_{i}+\beta_{3} E N V D_{i}+\beta_{4} C G D_{i}+\varepsilon \\
& E P S=\beta_{0}+\beta_{1} E C D_{i}+\beta_{2} S O D_{i}+\beta_{3} E N V D_{i}+\beta_{4} C G D_{i}+\varepsilon_{6} \\
& R O I=\beta_{0}+\beta_{1} E C D_{i}+\beta_{2} S O D_{i}+\beta_{3} E N V D_{i}+\beta_{4} C G D_{i}+\varepsilon_{7}
\end{aligned}
$$

Where

$\mathrm{ROE}=$ return on equity

EPS $=$ Earnings per share

ROI $=$ Return on investment

$\mathrm{ECD}=$ Economic disclosure

SON $=$ Social Disclosure

ENVD = Environmental disclosure

$\mathrm{CGD}=$ Corporate governance disclosure

$\varepsilon 1=$ Stochastic or disturbance/error term.

$\mathrm{t}=$ Time dimension of the variables

$\alpha 0=$ Constant or intercept.

Method of Estimation and Testing

i. Panel data regression model specifications

Panel data can be estimated and analyzed in three different specification models. These are the correlation matrices the Fixed Effect Model (FEM) and the Random Effect Model (REM). In this study the fixed effect model is chosen over pooled OLS regression because of the advantages the former has over the latter.

\section{ii. Pooled Regression Model}

To obtain a reliable and unbiased estimated the analysis, this estimation method uses the classical linear regression assumptions which according to Albrigim Zappe and Winston, (2011) stipulate that the error term should be independently and normally distributed with zero mean and constant variance and more importantly must not correlated with the independent variables pooled OLS linear regression is given as follows:

$$
Y_{i t}=\beta_{0}+\beta_{1} X_{1 i t}+\beta_{2} X_{2 i t}+\beta_{3} X_{4 i t}+\beta_{4} X_{5 i t}+U_{i t}
$$

where $Y_{i t}$ is the dependent variable; $\beta_{0}$ is a constant term: $\mathrm{X}_{1}$, to $\mathrm{X}_{5}$, are the independent variables; $\beta_{1}$ to $\beta_{4}$ are slope parameters: $\mathrm{i} . . . \mathrm{n}$ refers to the cross-sectional units and $\mathrm{t}$ is the time period. Using this regression specification, the model or this study is thus written as Gujarat; (2009) opined that pooled OLS regression model has the advantage of being the simplest, easy to understand and interpret as compared to the other models but the model is associated with some weaknesses. 


\section{Iii. The fixed effect model}

The fixed effect mode is highly comparable to the pooled OLS regression model in the sense that the slope coefficient is the same for all cross sectional and that the intercept remains unchanged across time. Employing the fixed effect least-squares dummy variable (LSDV)approach the issue of heterogeneity is taken different intercepts for every cross sectional and (Brooks, 2008). The fixed model can be specified as $Y_{i t}=\alpha_{i}+\beta_{1} X_{1 i t}+\beta_{2} X_{i t}+\beta_{3} X_{i t}+\beta_{4} X_{i t}+U_{i t}$

\section{Random Effects}

Random effects focus on the relationship with the study sample as a whole; thus, the samples are randomly selected, as opposed to using the entire population. The total sample regression (a function of the random effect) can be expressed as:

$$
\begin{aligned}
& R O E_{i t}=\sum_{j=1}^{N} \beta_{0}+f\left(\beta_{1} E C D+\beta_{2} S O D+\beta_{3} E N V D+\beta_{4} C G D+\beta_{5}+U \ldots \cdots \cdots \cdots\right. \\
& E P S_{i t}=\sum_{j=1}^{N} \beta_{0}+f\left(\beta_{1} E C D+\beta_{2} S O D+\beta_{3} E N V D+\beta_{4} C G D+\beta_{5}+U \ldots \ldots \cdots \cdots\right. \\
& R O I_{i t}=\sum_{j=1}^{N} \beta_{0}+f\left(\beta_{1} E C D+\beta_{2} S O D+\beta_{3} E N V D+\beta_{4} C G D+\beta_{5}+U \ldots \ldots \cdots \cdots\right.
\end{aligned}
$$

If this is represented with random variables, then $\beta_{o j}=\bar{\beta}_{0}+\mu_{j}$, which indicates that the difference occurs randomly, and the expectation value of $\beta_{o i}$ is $\bar{\beta}_{0}{ }^{5} \cdot 13$

\section{Results and Discussion}

This section presents analysis and findings of the study as set out in the research objective and research methodology. The study sought to establish the effect of sustainable reporting on the profitability indicators of quoted firms in Nigeria. Results in the tables below contain details on the effect of sustainable reporting on the profitability indicators of the 20 selected quoted firms in Nigeria.

Table i: the effect of sustainable reporting on the return on equity of quoted firms in Nigeria.

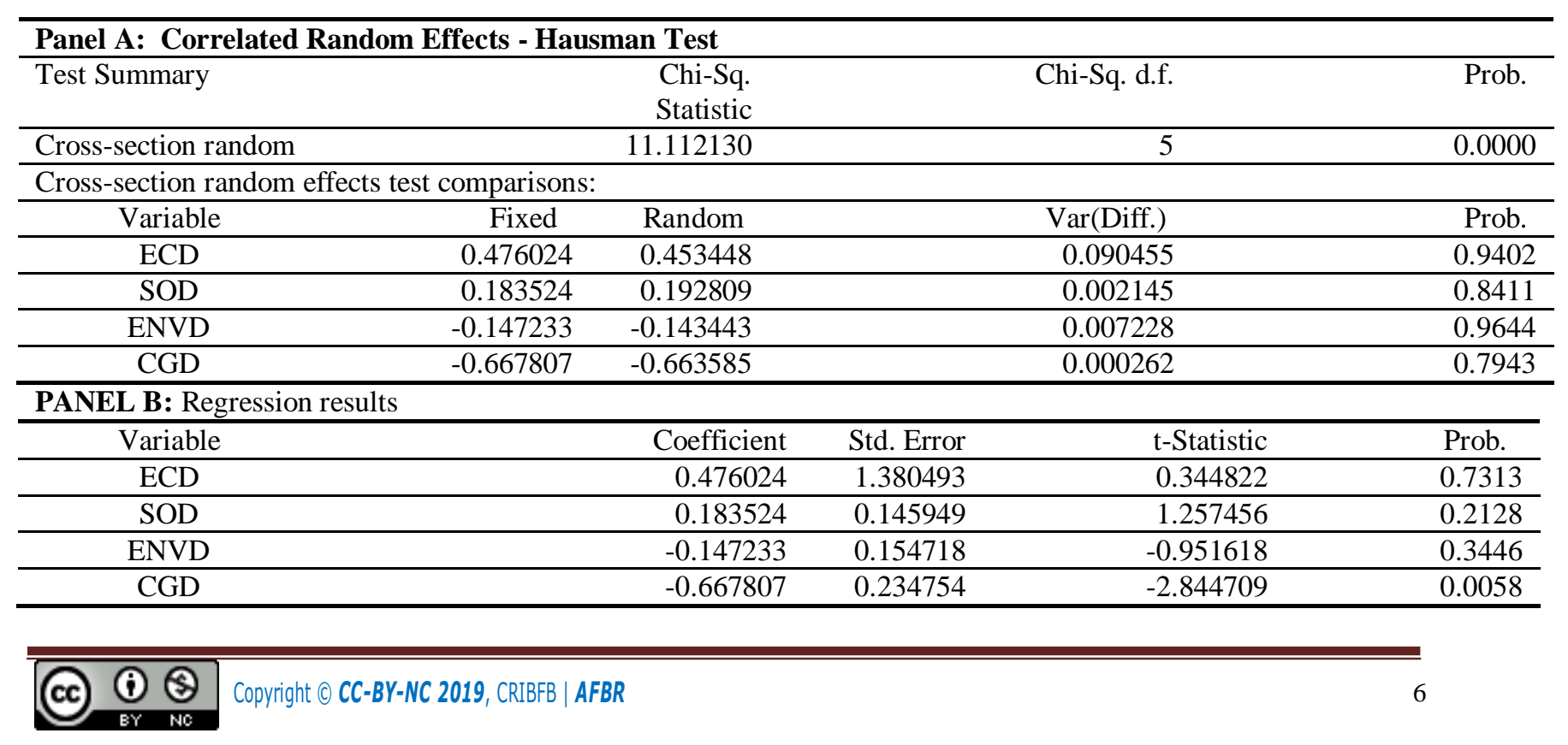




\begin{tabular}{|c|c|c|c|}
\hline $\mathrm{C}$ & 10.18255 & 7.384264 & 0.0000 \\
\hline \multicolumn{4}{|c|}{ Effects Specification } \\
\hline \multicolumn{4}{|c|}{ Cross-section fixed (dummy variables) } \\
\hline R-squared & 0.650012 & Mean dependent var & 10.19322 \\
\hline Adjusted R-squared & 0.480730 & S.D. dependent var & 1.292761 \\
\hline S.E. of regression & 1.081038 & Akaike info criterion & 3.186850 \\
\hline Sum squared resid & 81.80496 & Schwarz criterion & 3.742363 \\
\hline Log likelihood & -123.4082 & Hannan-Quinn criter. & 3.410865 \\
\hline F-statistic & 3.014502 & Durbin-Watson stat & 1.265173 \\
\hline Prob(F-statistic) & 0.000412 & & \\
\hline
\end{tabular}

\section{Source: extract from E-View 9.0}

Panel A of the results test the validity of fixed and random effect, from the results the probability of the Hausman test is less than the critical value of 0.05 , therefore fixed effect result is accepted. Panel B presents the regression effect of sustainable accounting on the profitability indices of Nigeria quoted firms. The results proved that 65 percent variation on the return on equity of the quoted firms can be explained by variation on the four predictor variables on sustainable reporting. Probability of F-statistics found that the model is statistically significant while the Durbin Watson Statistics proved the absence of serial autocorrelation. The probability coefficient of the variables found that there are no statistical differences between the fixed and the random effect. Regression coefficient of the variables justifies that economic disclosure and social disclosure have positive but insignificant effect on return on equity of the selected firms while environmental and corporate governance disclosure have negative and insignificant effect on return on equity.

Table ii: the effect of sustainable reporting on earnings per share of quoted firms in Nigeria.

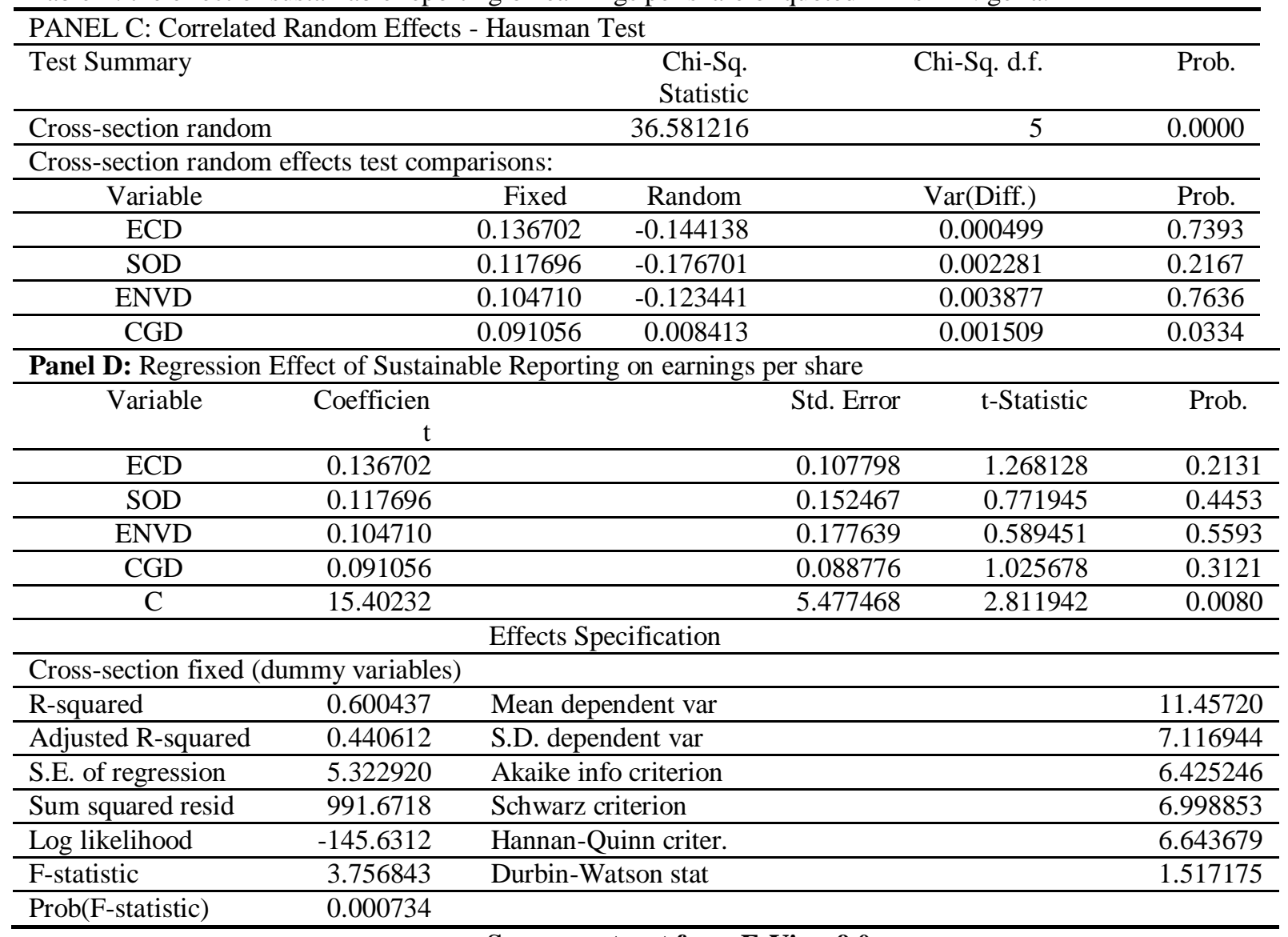

Source: extract from E-View 9.0 
Again Panel $\mathrm{C}$ of the results justifies the validity of fixed effect, from the results the probability of the Hausman test is less than the critical value of 0.05 , therefore fixed effect result is accepted. The differences between the fixed and random effect is statistically not significant. From panel D, the results found that 60 percent variation on the earnings per share of the firms can be predicted by variation on the four predictor measures of sustainable reporting, this justifies by the significant of the f-statistics and probability while Durbin Watson statistics proved the absence of serial autocorrelation. The beta coefficient of the variables proved that all the predictor variables have positive and insignificant effect on earnings per share of the firms.

Table iii: the effect of sustainable reporting on earnings per share of quoted firms in Nigeria.

\begin{tabular}{|c|c|c|c|c|c|}
\hline Test Summary & & $\begin{array}{l}\text { Chi-Sq. } \\
\text { Statistic }\end{array}$ & Chi-Sq. d.f. & & Prob. \\
\hline Cross-section random & & 6.809936 & 4 & & 0.1463 \\
\hline \multicolumn{6}{|c|}{ Cross-section random effects test comparisons: } \\
\hline Variable & Fixed & Random & Var(Diff.) & & Prob. \\
\hline ECD & -0.071848 & 0.507468 & 0.278045 & & 0.2719 \\
\hline SOD & 0.191573 & 0.255089 & 0.001098 & & 0.0452 \\
\hline ENVD & 0.204147 & 0.242534 & 0.000344 & & 0.0385 \\
\hline CGD & -0.199820 & -0.096867 & 0.009577 & & 0.2928 \\
\hline \multicolumn{6}{|c|}{ Panel F: Regression Effect of Sustainable Reporting on Return on Investment } \\
\hline Variable & $\begin{array}{r}\text { Coefficien } \\
\mathrm{t}\end{array}$ & Std. Error & & t-Statistic & Prob. \\
\hline ECD & 0.507468 & 0.133505 & & 3.801108 & 0.0006 \\
\hline SOD & 0.255089 & 0.082570 & & 3.089357 & 0.0041 \\
\hline ENVD & 0.242534 & 0.089788 & & 2.701187 & 0.0108 \\
\hline CGD & -0.096867 & 0.166405 & & -0.582116 & 0.5644 \\
\hline $\mathrm{C}$ & 0.678448 & 0.355450 & & 1.908701 & 0.0650 \\
\hline \multicolumn{6}{|c|}{ Effects Specification } \\
\hline & & & & S.D. & Rho \\
\hline Cross-section random & & & & 0.820470 & 0.8612 \\
\hline Idiosyncratic random & & & & 0.329343 & 0.1388 \\
\hline \multicolumn{6}{|c|}{ Weighted Statistics } \\
\hline R-squared & 0.843470 & Mean dependent var & & & 0.485215 \\
\hline Adjusted R-squared & 0.824497 & S.D. dependent var & & & 0.908805 \\
\hline S.E. of regression & 0.351364 & Sum squared resid & & & 4.074075 \\
\hline F-statistic & 44.45550 & Durbin-Watson stat & & & 1.274413 \\
\hline Prob(F-statistic) & 0.000000 & & & & \\
\hline \multicolumn{6}{|c|}{ Unweighted Statistics } \\
\hline R-squared & 0.825726 & Mean dependent var & & & 2.191316 \\
\hline Sum squared resid & 36.37256 & Durbin-Watson stat & & & 0.252859 \\
\hline
\end{tabular}

\section{Source: extract from E-View 9.0}

Further Panel E of the results justifies the validity of random effect, from the results the probability of the Hausman test is less than the critical value of 0.05 , therefore fixed effect result is accepted. The differences between the fixed and random effect is statistically not significant. From panel F, the results found that 60 percent variation on the earnings per share of the firms can be predicted by variation on the four predictor measures of sustainable reporting, this justifies by the significant of the f-statistics and probability while Durbin Watson statistics proved the absence of serial autocorrelation. Beta coefficient of the variables proved that economic, social and environmental disclosure have positive effect on return on investment while corporate governance disclosure have negative effect on return on investment of the selected firms in Nigeria. The positive effect of the variables confirm the findings of Asuquo, Dada and Onyeogaziri (2018)that Economic Performance disclosure, Environmental Performance disclosure and Social Performance disclosure have no significant effect on return on asset of selected quoted firms in Nigeria. 
Findings of the study show that economic disclosures do not significantly affect return on equity of selected quoted firms in Nigeria. This result is plausible in real business situations. The performance of firms depend heavily on firms pricing and volume of sale rather than disclosures of figures from previous financial periods. This result contradicts the findings of Makori and Jagongo (2013), who posited that environmental accounting has a significant influence on profitability in India. The authors argued that disclosing firm' activities carried out for the community it is domiciled influences the customers' patronage of firms' products. The findings also showed that Environment disclosure have effect on earnings per share. This finding contradicts the position of Murray, Sinclair, Power and Gray (2006), who posited social and environmental performance disclosures do not significantly affect financial market performance in UK companies The result shows that Social disclosures significantly affect return on investment of firms. The social expenditure carried out by the company is usually a small part of the firms' total expense that is used to obtain profits of the firm. This result confirms Olayinka and Temitope (2011) results that corporate social responsibility disclosures significantly affect financial performance of firms. The social expenditure carried out by the company is usually a small part of the firms' total expense that this used to obtain profits of the firm.

\section{Conclusion and Recommendations}

Generally, disclosures about issues away from mandatory requirements of the regulatory standards do not significantly affect profits as seen by the results of this research. Stakeholders look out for information about the trading activities and valuation measures of items in the financial statement, though sustainability reporting highlights areas of new interest in financial accounting which may eventually become significant variables that influence performance measures of companies. Sustainability Reporting provides a framework to create value for stakeholders which translates to satisfying the interest of diverse group of stakeholders. This work is anchored on stakeholder theory since it is propagated by stakeholder theory that managers should manage a firm for the benefit of all stakeholders. This is in agreement with legitimacy theory which emphasize that organizations continually seek to ensure that they operate within the bounds, norms and expectations of their societies and therefore, a company should maintain its survival and continuity by voluntarily disclosing detailed information to stakeholders to prove it is a good citizen. From the findings, the study concludes that there is significant relationship between sustainable reporting and profitability of quoted firms in Nigeria. It therefore recommends that:

- Operating environment of the firms should be well examined and policies should be advanced to manage factors such as economic, social, environmental and corporate governance to leverage the environmental challenges and enhance profitability.

- Companies should ensure strict compliance to all form of sustainability reporting, All cost incurred in the process of business transaction should be properly reported in the financial statement and accounted for to enhance profitability of the firm .

\section{References}

Aggarwal, P. (2013). Impact of sustainability performance of company on its financial performance. A study of listed Indian companies.Global Journal of Management and Business Research Finance, 13 (11), 61- 69.

Aondoakaa, K. (2015). Impact of sustainability reporting on corporate performance of selected quoted companies in Nigeria (Doctoral dissertation)

Asuquo, A I, dada e. T., \& Onyeogaziri U. R.(2018).The effect of sustainability reporting on corporate performance of selected quoted brewery Firms in Nigeria.

Babalola. \& Abiodun, Y. (2012). The impact of corporate social responsibility on firms ${ }^{\text {ee }}$ profitability in Nigeria. European Journal of Economics, Finance and Administrative Sciences, 45(1), 39-50.

Burhan, A. H., \& Rahmanti, A (2012). The impact of sustainability reporting on company performance, Journal of Economics, Business, and Accountancy Ventra 15 (2), 257 - 272.

Deegan, C. (2007). Organizational legitimacy as a motive for sustainability reporting, in Unerman, J.,

Duke II, J. \& Kankpang, K. (2013). Implications of corporate social responsibility for the performance of Nigerian firms, Advances in Management \& AppliedEconomics, 3 (5). 73-87.

Fontraine, C., Harman, A., \& Schmid, S. (2006). The stakeholder theory. Retrieved From http://www.edalys.fr/documents/stakeholders\%20theory.pdf on 22nd February, 2018. 10

Ivan, O.R. (2009). Sustainability in accounting basis: a conceptual framework. Annales Universittatis Apulensis Oeconomica 11 (1), 106-116.

Jasch, C. \& Stasiskiene, Z. (2005). From environmental management accounting to sustainability management accounting. Environmental Research, Engineeringand Management 4(34). 77-88. 
Kent, P. \& Stewart, J. (2008). Corporate governance and Disclosure on the transition to international financial Reporting standards. Retrieved from http://epublications.board.eed.au/business_pabs/130 on 22nd October, 2011.

Khaveh, A., Nikhashemi, S. R., Yousefi, A. \& Haque, A. (2012). Voluntary sustainability disclosure, revenue, and shareholders wealth - A perspective from Singaporean companies. Business Management Dynamics 1(9), 06-12.

KPMG. (2015). The KPMG survey of corporate responsibility Reporting 2015. KPMG.

Makori, D. M \& Jagongo, A. (2013). Environmental Accounting and firm profitability: An empirical analysis of selected firms listed in Bombay Stock Exchange, India. International Journal of Humanities and Social Sciences, 3 (8), 167-179.

Makori, D. M \& Jagongo, A. (2013). Environmental Accounting and firm profitability: An empirical analysis of selected firms listed in Bombay Stock Exchange, India. International Journal of Humanities and Social Sciences, 3 (8).

Munasinghe, M. A. T. K \& Kumara, D .C. U. (2013). Impact of disclosure of corporate social responsibility on corporate financial performances of plantations companies in Sri-Lanka. Journal of emerging trends in Economics and Management sciences, 4(3), 371-376.

Munasinghe, M. A. T. K \& Kumara, D .C. U. (2013). Impact of disclosure of corporate social responsibility on corporate financial performances of plantations companies in Sri-Lanka. Journal of emerging trends in Economics and Management sciences, 4(3), 371-376.

Nze, D.O., Okoh., J. \& Ojeogwu, I.C(2016). Effect of Corporate Social Responsibility on earnings of quoted firms in Nigeria. ESUT Journal of Accountancy (1), 260-267

Olayinka, M.U. \& Temitope, O.F. (2011). CSR and financial performance: The Nigerian experience. Journal of Economic and Sustainability Development, 3(4), 44-54

Onyekwelu \& Ekwe (2014). Does corporate social responsibility predicate good financial performance? ESUT Journal of Management Sciences, 8(1)1-10

Onyekwelu, U.L. \& Ugwuanyi, B. U. (2014). Corporate social accounting and the enhancement of information disclosure among firms: A study of selected firms in Nigeria. Journal of Economics and Sustainable Development. 5(6), 35-44.

Pandey, I. M. (2015). Financial management(9th ed.). New Delhi: Vikas Publishing House PVT Ltd

Perrin, F. \& Tencati, A. (2006). Sustainability and Stakeholder management: the need for new corporate performance evaluation and reporting systems. Business Strategy and the Environment, 15, $296-308$.

Popa, A., Blidisel, R. \& Bogdan, V. (2009). Transparency and disclosure between theory and practice, A case study of Romania, Proceedings of Fikusz "e09 Symposium for Young researchers. Retrieved from http://www.kgk.bmf.hu/fikusz on 14th September, 2011.

An Empirical Examination of the relationship between corporate social responsibility and profitability. Academy of Management Journal, 28 (2) 446-463.

Robbins, R. (2011). Does Corporate Responsibility increase profit? Retrieved from http//www.businessethics.com on 14th September, 2011.

Yahya, H.Y., \& Ghodratollah, B. (2014). The effect of disclosure level of CSR on corporate financial performance in Tehran stock exchange. International Journal of Accounting Research, 1(11), 43-51.

\section{Copyrights}

Copyright for this article is retained by the author(s), with first publication rights granted to the journal.

This is an open-access article distributed under the terms and conditions of the Creative Commons Attribution license (http://creativecommons.org/licenses/by/4.0/) 